\title{
The Correlation of Students' Interest and Vocabulary Mastery Toward Writing Skill
}

\author{
Fitria Wulansari, Muh. Asrori, Dewi Sri Wahyuni \\ English Education Department \\ Sebelas Maret University
}

email : fitriawu93@gmail.com

\begin{abstract}
This research aimed to find out the correlation of: (1) students' interest in learning to writing skill; (2) vocabulary mastery to writing skill; and (3) students' interest in learning and vocabulary mastery simultaneously to writing skill. This study used a correlational method with a cluster random sample of 31 students of the eleventh grade students of SMK Batik 2 Surakarta in the academic year 2013/2014. The researcher used questionnaire, objective tests and essay test as the instrument to collect the data. Single and Multiple Linear Regression and Correlation were used to analyze the data. The research findings show that: (1) students' interest in learning brings $39.69 \%$ contribution to writing skill; (2) vocabulary mastery brings $40 \%$ contribution to writing skill; and (3) students' interest in learning and vocabulary mastery simultaneously bring 47.98\% contribution to writing skill.
\end{abstract}

Keywords: correlation, students' interest in learning, vocabulary mastery, writing skill

Abstrak

Penelitian ini bertujuan untuk menemukan hubungan antara: (1) minat belajar dan ketrampilan menulis (2) penguasaan kosakata dan ketrampilan menulis, dan (3)minat belajar dan penguasaan kosakata terhadap ketrampilan menulis. Penelitian ini menggunakan metode korelasional dengan sampel acak pada 31 siswa SMK Batik2 Surakarta tahun ajaran 2013/2014. Peneliti menggunakan kuesioner, tes objektif dan tes essay sebagai instrumen dalam mengumpulkan data. Korelasi tunggal dan korelasi ganda digunakan untuk menganalisis data dalam penelitian ini. Hasil penelitian menunjukan bahwa: (1) minat belajar $39.69 \%$ berpengaruh terhadap ketrampilan menulis, (2) pengausaan kosakata $40 \%$ berpengaruh terhadap ketrampilan menulis, dan (3) minat belajar dan penguasaan kosakata $47.98 \%$ berpengaruh terhadap ketrampilan menulis.

Kata kunci: hubungan, minat belajar, penguasaan kosakata, keterampilan menulis 
Writing belongs to productive skill that should be developed by the teacher. Richard (2003: xv) states that writing is the most important skill that students need to develop. Students need more practice to develop their writing skill. The material taught by the teacher should appropriate with the syllabi and the curriculum used in the school. This research will focus on English teaching material taught in vocational high school.

Based on the syllabi for vocational high school, the standard competence requires the students' ability to communicate using English through written or oral form. It brings some English teachers tend to focus on one productive skill called writing skill. Writing belongs to productive skill which cannot be acquired easily. Writing is a process of transferring ideas into written form (The Ministry of National Education, 2009: 3). Harmer (2004: 4) says that writing is used for many varieties of purposes which produce in formal and informal form. NSW Department of Education and Training (1999: 12-13) mentions that there are two sorts of purposes for students' writing: (1)community purposes: it is related to the needs of the communication between individual, home and workplace; (2)academic purposes: it is related to the needs of making the assignments which are used to fulfill the academic standard in school. The writers should think about the idea first before they start to write. They have to pay attention about the purpose of writing and the target readers. The form of their writing can be in formal or informal form. The formal form is used in the formal occasion to make an assignment to fulfill the academic standard. While the informal one is used to keep in the communication one to another. 
Writing has some aspects to make it perfect. Ministry of National Education (2009: 3) says that writing accurately involves some components of writing: 1) spelling correctly; 2) forming letters correctly; 3) writing legibly; 4) punctuating correctly;5) using correct layouts; 6) choosing the right vocabulary; 7) using grammar correctly; 8) joining sentences correctly and 9) using paragraphs correctly. As one of the aspects of writing, teachers cannot neglect vocabulary mastery in teaching writing. It is in line with Brown (2003: 221) that writing needs to use an acceptable core vocabulary and appropriate word order and it should be followed with the conventions of spelling, punctuation and capitalization. In developing their writing skill, students' should have the knowledge of word they will use to write.

Kamil and Hiebert (2005: 3) defines vocabulary is the knowledge of meanings of words. The meaning of words is used in order to avoid either ambiguous or different interpretation when communicating. Vocabulary is a core component of language competence and determines how well the learners can speak, listen, read, and write (Richard and Renandya, 2002: 255). Vocabulary is a large number of words that one should know when he wants to learn about foreign language. The more number of words mastered, the easier he use it to communicate.

In learning foreign language, students need to have an impulse from their own self. It is called interest. Interest plays important role in one's activity in the daily life, including the field of education. Renninger (in Preiss and Sternberg, 2010: 111) states that interest is described as a close interaction of the person and 
the environment. Interest is a connector between the person and the thing or the environment he interested on. Interest has big role to improve learning process. Interest in the content will be learned is the most movement power of self to motivate to study (Oser, 2013: 20). Ones who learn based on interest will have more effort to study. Interest in learning can improve the effort of the students to learn.

To reach the success in learning, students need to know learning interest. Learning is a process to obtain the knowledge of a subject or skill by study, experience or instruction (Brown, 2007: 7). Santrock (2011: 201) adds that learning is a relatively permanent influence on behavior, knowledge, and thinking skills that comes through experience. Learning is an activity which influences one's behavior, knowledge, and thinking skills by study, experience or instruction. Students were seen to have different needs and interest in a subject. Their interest will influence their motivation in learning. Interest in learning makes the learning process more effective and makes the students understand better and faster.

Renninger (in Preiss and Sternberg, 2010: 112-117) mentions that interest has four phases of its development and the students have different reaction in each phase: a) Triggered situational interest: students have so little information about the content or the task they will do; b) maintained situational interest: students will develop their knowledge about the content; c) emerging individual interest: the students in this phase are motivated to work on their writing to express their idea and have their ideas respected; d) well-developed individual interest: the students will have positive feelings in getting feedback and continue to develop 
their understanding of the content. Since interest in the content influence the students' motivation, the students will be motivated to learn about how to write when they have interest on it. As stated by Renninger (2010: 124) that the students are motivated to write when they have positive feelings on writing.

The aims of this research is to know whether: (1) there is a correlation of students' interest in learning to writing skill of the eleventh grade students of SMK Batik 2 Surakarta in the academic year 2013/2014, (2) there is a correlation of vocabulary mastery to writing skill of the eleventh grade students of SMK Batik 2 Surakarta in the academic year 2013/2014, and (3) there is a correlation of students' interest in learning, vocabulary mastery simultaneously to writing skill of the eleventh grade students of SMK Batik 2 Surakarta in the academic year $2013 / 2014$.

\section{Research Methods}

The research used correlational method which is used to find the correlation between the variables. There are two kinds of variables in this research, independent variable and dependent variable. This research has three variables, namely: 1) the independent variables (students' interest and vocabulary mastery); and 2) the dependent variable: students' writing skill. The researcher examines the correlation between vocabulary mastery and students' writing skill. Then she comes to examine the correlation between students' interest in learning English and students' writing skill. Finally, she examines the correlation between students' interest, vocabulary mastery and students' writing skill. 
The research had 31 student-respondents which were selected randomly from the eleventh grade students of SMK Batik 2 Surakarta in the academic year 2013-2014. The tests were administered at SMK Batik2 Surakarta over two days. Researcher used questionnaire to collect the students' interest data and test to measure students' vocabulary mastery and writing skill. The tests were the objective test in the form of multiple choices test for vocabulary mastery and an essay test for writing skill. Before administering the tests, the researcher explained about the test instruction and the purpose of this research. The first day of taking the data was giving them the questionnaire about interest in learning. They take 60 minutes to fulfill the questionnaire. After fulfilling the questionnaire, the students were asked to do the vocabulary mastery test for 90 minutes. The second day testing was writing skill test to measure students' ability in writing for about 40 minutes.

\section{Research Findings}

In this part of the research, the correlation between students' interest in learning and their writing skill, the correlation between vocabulary mastery and their writing skill and the correlation between students' interest and vocabulary mastery simultaneously, toward writing skill were presented. The results showed that participants of students' interest in learning, vocabulary mastery and writing skill scores are normally distributed. So, the tests of three variables in this research were valid and there is no diffraction especially in the small sample. The result of regression is linear and significant. So, the rise and the fall of writing 
skill are followed by the rise and the fall of students' interest in learning and vocabulary mastery.

The first finding came from the correlation between students' interest and writing skill. Based on the computation of linearity and significance of regression test of students' interest $\left(\mathrm{X}_{1}\right)$ and writing skill $(\mathrm{Y})$, the result is linear and significant. The computation showed that the value of $F_{o}$ (F-obtained) is 0.585 . The value of $F_{t}$ for df 12 and 17 at the level of significance $\alpha=0,05$ is 2.38 . Because $F_{o}(0.585)$ is lower that $F_{t}(2.38)$, it can be concluded that the regression is linear. While, the computation showed that the value of $F_{o}$ is 19.087 . The value of $F_{t}$ for df 1 and 29 at the level of significance $\alpha=0.05$ is 4,18 . Because $F_{o}$ (19.087) is higher than $F_{t}(4.18)$, it can be concluded that the regression is significant. It is also showed that the value of coefficient $a=38.213$ and $b=$ 0.312. Because the equation is linear and significant so, it can be used to predict the correlation between students' interest $\left(\mathrm{X}_{1}\right)$ and writing skill $(\mathrm{Y})$; it showed that the mean of writing skill (Y) would increase 0.312 if the students' interest $\left(\mathrm{X}_{1}\right)$ was increased one score in the constant score of 38.213 .

When examining the simple correlations associated with the regressions, the researcher noted that the performance of students' interest was related with performance of writing skill $(\mathrm{r}=0.396, p=0.05)$. Then, this value is compared to $\mathrm{r}$-table at the significance level of $5 \%$ for $\mathrm{N}=31$, it is 0.355 . It means that $\mathrm{rx} 1 \mathrm{y}$ is higher than rt. It means that the correlation is significant; so, there is a positive correlation between students' interest (X1) and writing skill (Y). Based on the analysis above, it can be concluded that the null hypothesis $\left(\mathrm{H}_{\mathrm{o}}\right)$ is rejected and 
the alternative hypothesis $\left(\mathrm{H}_{\mathrm{a}}\right)$ is accepted. The conclusion is that there is a positive correlation between students' interest in learning English $\left(\mathrm{X}_{1}\right)$ and writing skill (Y).

The second finding came from the correlation between vocabulary mastery and writing skill. Based on the computation of linearity and significance of regression test of vocabulary mastery $\left(\mathrm{X}_{2}\right)$ and writing skill $(\mathrm{Y})$, the result is linear and significant. The computation showed that the value of $F_{o}$ (F-obtained) is 1.035 . The value of $F_{t}$ for $\mathrm{df} 12$ and 17 at the level of significance $\alpha=0.05$ is 2.38. Because $F_{o}(1.035)$ is lower that $F_{t}(2.38)$, it can be concluded that the regression is linear. The computation showed that the value of $F_{o}$ is 19.330 . The value of $F_{t}$ for $\mathrm{df} 1$ and 29 at the level of significance $\alpha=0.05$ is 4.18 . Because $F_{o}$ (19.330) is higher than $F_{t}(4.18)$, it can be concluded that the regression is significant. It is also showed that the value of coefficient $a=53.846$ and $b=$ 0.277. Because the equation is linear and significant so, it can used to predict the correlation between vocabulary mastery $\left(\mathrm{X}_{2}\right)$ and writing skill $(\mathrm{Y})$; it showed that the mean of writing skill(Y) would increase 0.277 if the vocabulary mastery $\left(\mathrm{X}_{2}\right)$ was increased one score in the constant score of 53.84 .

The result showed that the correlation coefficient $(\mathrm{r}=0.40, p=0.05)$ is considered as a positive correlation. Then, this value is compared to r-table at the significance level of $5 \%$ for $\mathrm{N}=31$, it is 0.355 . It means that $\mathrm{rx}_{2} \mathrm{y}$ is higher than $\mathrm{r}_{\mathrm{t}}$. It means that the correlation is significant; so, there is a positive correlation between vocabulary mastery $\left(\mathrm{X}_{2}\right)$ and writing skill $(\mathrm{Y})$. Based on the analysis above, it can be concluded that the null hypothesis $\left(\mathrm{H}_{\mathrm{o}}\right)$ is rejected and the 
alternative hypothesis $\left(\mathrm{H}_{\mathrm{a}}\right)$ is accepted. The conclusion is that there is a positive correlation between vocabulary mastery $\left(\mathrm{X}_{2}\right)$ and writing skill $(\mathrm{Y})$.

The third finding came from the correlation between students' interest and vocabulary mastery simultaneously and writing skill. The technique used here is regression analysis and multiple correlations. From the computation of multiple regressions, it is found that the coefficient of $\mathrm{a}_{0}, \mathrm{a}_{1}$, and $\mathrm{a}_{2}$ are $38.213 ; 0.312$; and 0.277. Therefore, the multiple regression equation of $\mathrm{Y}$ on $\mathrm{X}_{1}$ and $\mathrm{X}_{2}$ becomes; $\mathrm{Y}^{\wedge}$ $=38.213+0.312 \mathrm{X}_{1}+0.277 \mathrm{X}_{2}$. The testing result of the significance of regression for $F_{o}$ is 12.92 . This result is compared to F-table at the significance level of $5 \%$ and degree of freedom $(\mathrm{df}=2: 29)$ is 3.33. It means that $\mathrm{F}_{\mathrm{o}}(12.92)$ is higher than $F_{t_{(2,29)}}=(3.33)$, so $F_{o}$ is significant. It showed that the equation of $Y^{\wedge}=38.213+$ $0.312 \mathrm{X}_{1}+0.277 \mathrm{X}_{2}$ is linear and significant. Because the equation is linear and significant so, it can used to predict the correlation between students' interest $\left(\mathrm{X}_{1}\right)$ and vocabulary mastery $\left(\mathrm{X}_{2}\right)$ and writing skill $(\mathrm{Y})$; it means that in every one score increase from vocabulary mastery $\left(X_{1}\right)$ together with English interest $\left(X_{2}\right)$ it increases 0.354 of writing skill (Y) in the constant score of 38.213 .

From the multiple correlation analysis, it is found that the multiple correlation coefficients $(\mathrm{R})$ is 0.693 . then F-obtained which is 12.92 is greater than F-table at $5 \%$ level of significance for $\mathrm{N}=31$ which is 3.33 . So, it can be said that the multiple correlation coefficient is significant. Based on the analysis above, it can be said that the null hypothesis $\left(\mathrm{H}_{\mathrm{o}}\right)$ is rejected, and the alternative hypothesis $\left(\mathrm{H}_{\mathrm{a}}\right)$ is accepted. The conclusion is that there is positive correlation between 
students' interest $\left(\mathrm{X}_{1}\right)$ and vocabulary mastery $\left(\mathrm{X}_{2}\right)$ simultaneously writing skill (Y).

\section{Discussion}

For the first aim, the researcher was interested in determining whether there is a correlation between students' interest to writing skill. Based on the findings, the good writing skill of students is consistent with their interest in learning. The result confirmed that there is a positive significant correlation $\left(t_{0}=\right.$

$4,368>t_{t=1.70)}$ between students' interest and writing skill. It is also found that $r^{2}$ (coefficient of determination) is 0.3969 . It means that $39.69 \%$ variance of writing skill is determined by students' interest.

Interest affects students' behavior, knowledge, and thinking skills. When students have interest in learning, it will change on how they act and how they think. The students will pay more attention at the material they learned. Interest is related to the students' pleasure to learn. Having pleasure feeling to English lesson motivates them to do the activity and join the English learning process. The student who has interest will be motivated to involve in. Those explanations are in line with the recent studies that interest is conceptualized as more specific than intrinsic motivation and interest is positively linked to deep learning (Santrock, 2011). It makes interest deeper than motivation. The student who has interest will be more motivated to do the activity in the classroom than the student who has no interest.

Interest in learning English will lead them to cover all of the English skill. Interest draws students to give more attention to learn something. They will think 
about how to gather more information. When they have enough information, they will express their idea in written form. It is in line with Renninger (in Preiss and Sternberg, 2010) that the students in emerging individual interest phase are motivated to work on their writing.

The second aim was finding out the correlation between vocabulary mastery and writing skill. The result confirmed that there is a positive significant correlation $\left(t_{0}=4.760>t_{t}=1.70\right)$ between vocabulary mastery and writing skill. It is also found that $\mathrm{r}^{2}$ (coefficient of determination) is 0.40 . It means that $40 \%$ variance of writing skill is determined by vocabulary mastery.

For the second aim, the vocabulary mastery was assessed by spelling, grammar, words meaning and word formation was correlated positively with writing. There are two kinds of vocabulary: receptive and productive vocabulary. Writing is productive skill, and then it needs productive vocabulary to produce a written product in order to deliver the writers' thought to other. Thus, in line with Schmitt (2000: 4) that a word is known as receptive knowledge when it is connected with listening and reading and when a word is produced when speaking or writing, it is considered as productive knowledge. Writing skill needs vocabulary to make a written product. If there is no word, then it will be no sentence. Since vocabulary is one of the elements of writing skill, we cannot neglect the important of it. Vocabulary is a core component of language competence and determines how well the learners can speak, listen, read, and write (Richard and Renandya, 2002: 255). 
The last result said that there is a positive correlation between students' interest and vocabulary mastery simultaneously and writing skill. The result confirmed that $F_{o}(4.665)$ is higher than $F_{t}(2.29)$ for alpha $=0.05$ is 3.33 , then it means that the coefficient of multiple correlation $(\mathrm{R})$ is significant. It also found that $\mathrm{R}^{2}$ is 0.480 . It means that $40 \%$ variance of writing skill is determined by students' interest and vocabulary mastery. And the result is there is positive correlation between students' interest and vocabulary mastery simultaneously and writing skill.

It can be seen that the students who have interest in learning will get better score in writing. Besides, those mastering the vocabulary will have high score in writing test. Interest in learning can make the students enjoy learning English. When students have interest in learning, they will have no burden to involve in the classroom activity. It draws the attention of the students to focus in learning English.

English has four skills that should be mastered by the students. Writing is one of the four English skills. Writing is one of the English skills that should be mastered by the students. Vocabulary has important role to help the students learn about English skills. The students need to know about the appropriate word used in writing. So, vocabulary mastery is important in writing, because without knowing the appropriate vocabulary, students will find difficulties to share their ideas in to writing. Mastering vocabulary will help the students to transform their ideas in to written form with the appropriate word. 


\section{Conclusion and Suggestion}

The empirical analysis showed that there is a positive correlation between students' interest in learning and writing skill, there is a positive correlation between vocabulary mastery and writing skill, and there is a positive correlation between students' interest in learning and vocabulary mastery simultaneously, and reading skill of the eleventh grade students of SMK Batik 2 Surakarta in the academic year $2013 / 2014$. Judging by quantity, the vocabulary mastery brings more contribution (40\%) to writing skill than the contribution of students' interest in learning to writing skill (39.69\%). The students' interest in learning and vocabulary mastery simultaneously brings the highest contribution to writing skill (47.98\%). Therefore, the two variables cannot be ignored in the effort to improve the students' writing skill.

It is suggested for the teachers that, they should enrich the students' vocabulary mastery trough vocabulary building task. The teacher may use picture or things around to make it easier for the students to understand. They also should improve the students' interest by creating more interesting material and situation in the classroom. When the teacher can create an interactive class, the students will have no burden in joining the learning process. It makes the learning process better and faster.

For the students, it is important to enrich their vocabulary mastery and increase their interest in learning. When the students have interest in learning, they will be happy to involve in the learning process and catching the material taught by the teacher easily. The students should increase their vocabulary 
mastery to support their writing skill. They may start to make a word list from a text or book which they do not know about the meaning of that word. Finally, it is suggested for the other researchers that the findings of the research could be used as reference to conduct the better research which is related to writing skill.

\section{References:}

Brown, H. Douglas. 2004. Language Assessment. New York: Pearson Education Inc.

Brown, H. Douglas. 2007. Principles of Language Learning and Teaching. $5^{\text {th }}$ Ed. USA: Pearson Education, Inc.

Harmer, Jeremy. 2004. How to Teach Writing. Longman: Pearson Education Limited.

Hatch, Evelyn \& Brown, Cheryl. 1995. Vocabulary, Semantics and Language Teaching. Cambridge: Cambridge University Press.

Hiebert, Elfrieda H. \& Kamil, Michael L. 2005. Teaching and Learning Vocabulary: Bringing Research to Practice. New Jersey: Lawrence Erlbaum Associates Inc.

Hughes, Rebecca. 2005. English in Speech and Writing Investigating language and literature. New York: Routledge28 West 35th Street.

Laufer, Batia. 2007. The Lexical Plight in Second Language Reading. In James Coady \& Thomas Huckin

Milton, James. (2009). Measuring Second Language Vocabulary Acquisition. Great Britain: Short Run Press Ltd.

Musyawarah Guru Mata Pelajaran. 2009. Teaching Writing. Jakarta: Author.

NSW Department of Education and Training. (1999).Focus on Literacy: Writing. Curriculum Support Directorate. 0731359275

Oser, Fritz. 2013. Models of Moral Motivation. In Karin Heinrich, Fritz Oser, \& Terence Lovat (Ed), Handbook of Moral Motivation: Theories, Models, Apllications (pp.7-24). The Netherlands: Sense Publisher.

Raimes, Ann. 1983. Technique in Teaching Writing. Oxford: Oxford University Press. 
Renninger, K. Ann. 2010. Working With and Cultivating the Development of Interest, Self-Effi cacy, and Self-Regulation. In David D. Preiss\& Robert J. Sternberg(Ed), Innovations in Educational Psychology: Perspectives on Learning, Teaching, and Human Development. (pp. 107-134). New York: Springer Publishing Company.

Richard, Jack C. (Ed). (2003). Second Language Writing. New York: Cambridge University Press.

Santrock, John W. 2011. Educational Psychology. $5^{\text {th }}$ Ed. New York: Mac Graw Hill.

Sciefele, Ulrich. 2009. Situational and Individual Interest. In Kathryn R. Wentzel Allan Wigi eld (Ed), Handbook of Motivation at School. (pp. 197-222). New York: Routledge.

Scmhitt, Norbert. 2000. Vocabulary in Language Teaching. UK: Cambridge University Press.

Silvia, Paul J. 2006. Exploring The Psychology Of Interest. New York: Oxford university press inc.

Zimmerman, Cheryl Boyd. 2007. Historical Trends in Second Language Vocabulary Instruction. In James Coady \& Thomas Huckin (Ed.), Second Language Vocabulary Acquisition. (pp.5-19). USA: Cambridge University Press. 